\title{
Cystic Fibrosis with Paediatric Femoral Neck Stress Fracture: A Case Report and the Review of Literature
}

\author{
Pediatrik Femur Boyun Stres Kırığı Olan Kistik Fibroz: Bir Olgu Sunumu ve Literatürün \\ Gözden Geçirilmesi

\section{Abstract}

Cystic fibrosis is a common genetic disease of the white population with autosomal recessive inheritance. It may present with sinopulmonary, gastrointestinal, genitourinary, bone and joint findings. Osteoporosis, osteopenia, and fractures are musculoskeletal problems related to the disease. Although vertebral fractures are common, non-vertebral fractures have been reported rarely. In this case report, we present the case of a 9-year-old girl with osteopenia-induced femoral neck stress fracture caused by cystic fibrosis. During hospitalization for sinopulmonary infection, the patient presented to our clinic with left thigh pain without trauma. The left hip joint was examined and found to be clear. Anterior posterior X-ray examination of the patient, who had difficulty in stepping, revealed no displaced fracture. The patient was later diagnosed with type 2 Fullerton \& Snowdy fracture, and surgical fixation was ruled out. The patient was successfully treated with non-steroidal anti-inflammatory drugs and immobilization.

Keywords: Cystic fibrosis, stress fracture, paediatric femoral neck fracture

\section{Öz}

Kistik fibrozis otozomal resesif geçişli, beyaz ırkın sık görülen bir genetik hastalığıdır. Sinopulmoner, gastrointestinal, genitoüriner, kemik ve eklem bulguları ile karşımıza çıkabilir. Osteoporoz, osteopeni ve kırıklar hastalığa bağlı kas-iskelet sistemi sorunlarıdır. Vertebra kırıkları sık görülmekle birlikte nadiren vertebra dışı kırıklar bildirilmiştir. Biz olgu sunumumuzda kistik fibrozisin yol açtığı osteopeniye bağlı femur boyun stres kırığı olan 9 yaşındaki bir kız hastayı sunmaktayız. Sinopulmoner enfeksiyon nedeni ile yatışı esnasında, travmasız sol uyluk ağrısı ve yük vermede zorluk nedeni ile tarafımıza danışılan hastanın anterior posterior radyografik değerlendirmesinde patolojik bulguya rastlanmayıp, manyetik rezonans görüntüleme sonucunda sol femur boynunda deplase olmayan kırı görüntüsü saptandı. Fullerton \& Snowdy tip 2 olarak değerlendirilen hastaya cerrahi fiksasyon düşünülmedi. Non-steroid anti-enflamatuvar ilaç ve immobilizasyon ile başarılı şekilde tedavi edildi. Anahtar kelimeler: Kistik fibrozis, stres kırığı, çocuk femur boyun kırı̆ı

\section{Introduction}

Cystic fibrosis (CF) is an autosomal recessive disease predominantly seen in the Caucasian race. Prevalence is $1 / 2000$ 3500 per live birth. Skeletal findings related to CF are only seen in a limited group of patients. Bone manifestations of the disease are osteoporosis, osteopenia, and vertebral fractures. We present a case of a 9-year-old girl diagnosed with $C F$, having a femoral neck stress fracture.

\section{Case Report}

Informed consent was obtained from the mother of the patient because of the patient is under 18 years old. A nine-year- old female patient diagnosed with CF was consulted at our clinic with left hip pain while she was hospitalized because of pulmonary infection. The patient was also receiving treatment for type 1 diabetes mellitus last five years. She had left hip pain, radiating to the anterior thigh without any history of trauma. The range of motion of the left hip joint was full, with moderate pain. There was no other pathological orthopedic finding on physical examination. On pelvic anteroposterior $(A P)$ view $X$-ray, there was no sign of a fracture or periosteal reaction (Figure 1). Actual laboratory findings were; calcium: $8.9 \mathrm{mg} / \mathrm{dL}$, phosphor: $5.4 \mathrm{mg} / \mathrm{dL}$, magnesium: $1.8 \mathrm{mg} / \mathrm{dL}$, 25-hydroxyvitamin D: $32.12 \mathrm{ug} / \mathrm{L}$, parathormone: $26.54 \mathrm{ng} / \mathrm{L}$, osteocalcin: $5.81 \mathrm{ug} / \mathrm{L}, \mathrm{C}$-telopeptide: $0.98 \mathrm{ug} / \mathrm{L}, \mathrm{C}$-reactive protein (CRP): $21.8 \mathrm{mg} / \mathrm{L}$. Except for C-telopeptide height

Address for Correspondence/Yazışma Adresi: Yavuz Şahbat MD, Marmara University Faculty of Medicine, Department of Orthopedics and Traumatology, İstanbul, Turkey Phone: +90 5426193477 E-mail: yavuzsahbat@gmail.com ORCID ID: orcid.org/0000-0002-9963-5334 Received/Geliş Tarihi: 12.09.2019 Accepted/Kabul Tarihi: 09.11.2020

${ }^{\circ}$ Copyright 2021 by the Turkish Osteoporosis Society / Turkish Journal of Osteoporosis published by Galenos Publishing House. 
and CRP height, other tests were monitored in the reference range. Recent dual-energy $\mathrm{X}$-ray absorptiometry result was lumbar (L2-4) bone density 0,495 g/ $\mathrm{cm}^{2}$ (Z-score: 2.4). On magnetic resonance imaging $(\mathrm{MRI})$, left femoral neck stress fracture and surrounding bone edema were visible on the T2 sequence (Figure 2). After radiological evaluation, the fracture was classified as compression type, according to Fullerton \& Snowdy classification, and no surgical intervention was planned. The patient was followed with restricted weight bearing, non-steroidal anti-inflammatory drugs, and oral vitamin $D$ replacement therapy. Follow-up was planned and performed as 30 days without, 20 days partial, followed with full weight-bearing. On the $30^{\text {th }}$ day clinic visit, there was callus visible on pelvic AP X-ray (Figure 3). On third month visit, the patient was free of pain with a full range of motion and function.

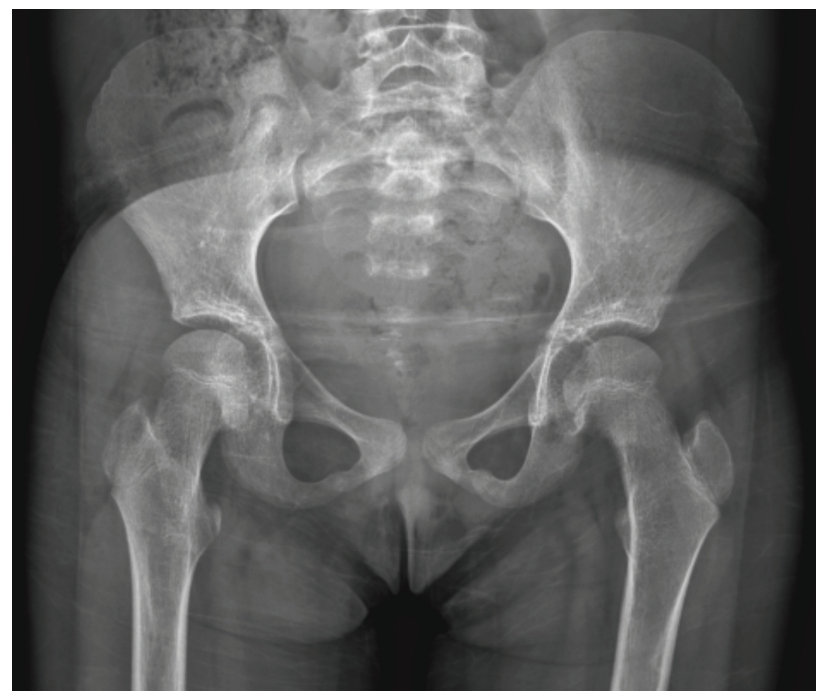

Figure 1. First $\mathrm{X}$-ray: There was no sign of a fracture or periosteal reaction

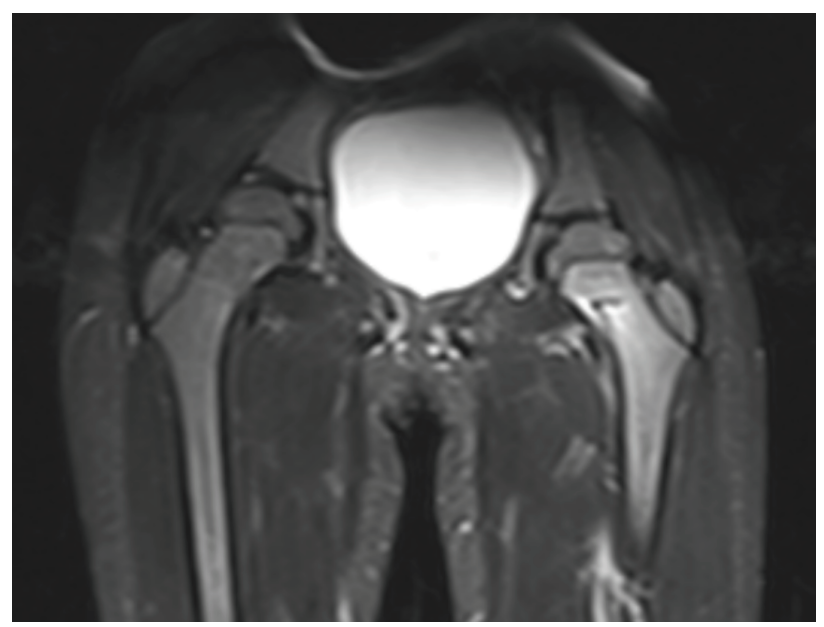

Figure 2. Magnetic resonance imaging: Left femoral neck stress fracture and surrounding bone edema were visible on the T2 sequence

\section{Discussion}

$\mathrm{CF}$ is a disease caused by a mutation of the transmembrane conductance regulator (CFTR) gene, located on the 7 . chromosome. CF; affects respiratory, gastrointestinal, and urinary systems, as well as the musculoskeletal system. Bone involvement includes mostly osteopenia and osteoporosis. Paccou et al. (1) reported in a study on adults with CF, the prevalence of osteoporosis, osteopenia, and non-vertebral pathological fractures; $23 \%, 38 \%$, and $19 \%$, respectively. The distribution of non-vertebral fractures on CF patients shows heterogeneity, and there are various studies with different results for most frequent fractured bones $(2,3)$.

Femoral neck fractures are uncommon injuries like less than $1 \%$ in all pediatric fractures, usually associated with significant trauma (4). Repetitive microtrauma may also cause femoral neck stress fractures (5). Femoral neck stress fractures are 1-7,2\% of all stress fractures.

Low bone mineral density (BMD) is one of the possible etiological factors for a stress fracture (6-9). Malnutrition, chronic infection, vitamin D insufficiency, hypogonadism, and low physical activity are primary factors for decreased BMD (10).

BMD of our patient checked 3 years ago was $0.560 \mathrm{~g} /$ $\mathrm{cm}^{2}$ (Z-score: -1.4), declined to $0.495 \mathrm{~g} / \mathrm{cm}^{2}$, (Z-score: -2.4) at the time of fracture. She was seven times hospitalized because of pulmonary infection and malnutrition in the last three years. On every hospitalization, she did not use intravenous corticosteroids but had inhalation corticosteroids for treatment, which is another factor predisposing low BMD (11). Z-score is significantly correlated with respiratory parameter forced expiratory volume in one second (FEV1) (12). FEV1 score 2 months before fracture is $51 \%$ (age normal 75-80\%). However, even with normal nutrition and mild disease may have low BMD (13). CF patients with F508del homozygous mutation have lower BMD. Our patient does not have this mutation (14).

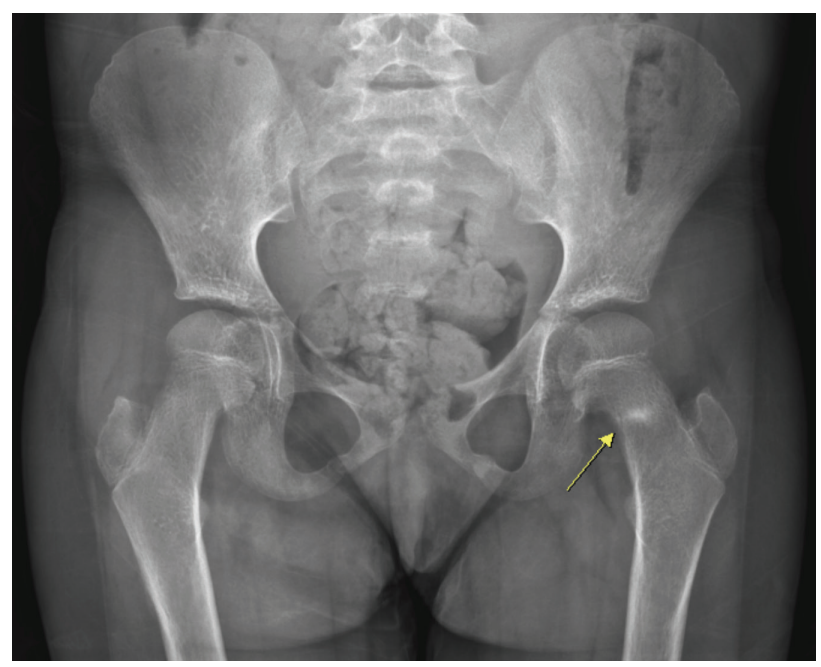

Figure $3.30^{\text {th }}$ day clinic visit; there was callus visible on pelvic anteroposterior X-ray 
A pediatric patient consulted because of hip and groin pain; transient synovitis, Perthes disease, infection, malignancy, and dysplasia should be ina differential diagnosis. The primary symptom for a femoral neck stress fracture is gradually worsening hip, anterior groin, and knee pain. Pain is elevated with weightbearing and activity, relieves with rest. The patient may have an antalgic gait pattern. Physical examination, patients avoid active hip movement, and passive motion causes pain and fear. The first used imaging modality is AP direct radiography. $15^{\circ}$ internal rotation X-ray may also be helpful for evaluation but has limited diagnostic value. MRI is a gold standard for evaluation $(6,15-17)$. Haddad et al. (6) used an MRI to define stress fractures and reported bone edema as the most frequent finding. The most common classification system for femoral neck stress fractures is Fullerton \& Snowdy classification, which is based on direct X-rays and bone scans (18). Fractures are classified as compression type, tension type, and displaced fractures according to this classification.

We do not think our patient's stress fracture is caused by repetitive trauma. Risk factors in our patient are Z-score declining from -1.4 to $-2.4 / \mathrm{cm}^{2}$, prepuberty, female gender, and low FEV1 score, steroid use (10).

Primary aims in the treatment of femoral neck fracture are to prevent avascular necrosis, coxa vara, and premature physeal closure. These complications depend on the amount of displacement (19). Biz et al. (20) successfully treated conservatively 1 of 4 femoral neck stress fractures, and they used dynamic hip screw fixation for other patients. We did not choose surgical intervention because of age, undisplaced fracture, and limited immediate activity expectations of the patient.

There are 2 case reports about femoral neck fractures in CF patients. Lim et al. (21) reported bilateral femoral neck fractures after grand mal epilepsy on a 34-year-old CF patient. The patient reported with prolonged usage of corticosteroids and malnutrition after recurrent pulmonary infection. These two factors decrease BMD and increase the risk of fracture as well as our patient. The patient was treated successfully with bilateral total hip arthroplasty and vitamin D support to increase BMD. Haworth et al. (22) successfully treated a 25-year-old patient with low BMD. The patient was deceased two years after surgery, and on bone biopsy, severe cortical and trabecular osteopenia was observed, which was not specific for osteomalacia or osteoporosis. Their new histomorphological findings suggest that bone disease caused by CF may be much more complicated.

There was no reported femoral neck stress fracture of a CF child.

Low BMD becomes a much more challenging issue because of the longer life expectancy of CF patients. Stress fracture should be in the differential diagnosis of a CF patient with joint and extremity pain without trauma. We suggest early monitorisation of bone quality because of possible early-onset low BMD.

\section{Ethics}

Informed Consent: Informed consent was obtained from the mother of the patient because of the patient is under 18 years old.

Peer-review: Externally and internally peer-reviewed.

\section{Authorship Contributions}

Surgical and Medical Practices: A.H.A., Concept: Y.Ş., Design: Y.Ş., A.H.A., Data Collection or Processing: Y.Ş. Analysis or Interpretation: Y.Ş., A.H.A., Literature Search: Y.Ş., Writing: Y.Ş.

Conflict of Interest: No conflict of interest was declared by the authors.

Financial Disclosure: The authors declared that this study received no financial support.

\section{References}

1. Paccou J, Zeboulon N, Combescure C, Gossec L, Cortet B. The prevalence of osteoporosis, osteopenia, and fractures among adults with cystic fibrosis: a systematic literature review with metaanalysis. Calcif Tissue Int 2010;86:1-7.

2. Haworth CS, Selby PL, Webb AK, Dodd ME, Musson H, McL Niven $R$, et al. Low bone mineral density in adults with cystic fibrosis. Thorax 1999;54:961-7.

3. Elkin SL, Fairney A, Burnett S, Kemp M, Kyd P, Burgess J, et al. Vertebral deformities and low bone mineral density in adults with cystic fibrosis: a cross-sectional study. Osteoporos Int 2001;12:36672.

4. Beaty JH, Kasser JR. Rockwood and Wilkins. Fractures in Children. Philadelphia: Lippincott, William \&Wilkins; 2010. p. 769-96.

5. Palocaren T. Femoral Neck Fractures in Children: A Review. Indian J Orthop 2018;52:501-6.

6. Haddad FS, Bann S, Hill RA, Jones DH. Displaced stress fracture of the femoral neck in an active amenorrhoeic adolescent. Br J Sports Med 1997;31:70-2.

7. Scott MP, Finnoff JT, Davis BA. Femoral neck stress fracture presenting as gluteal pain in a marathon runner: case report. Arch Phys Med Rehabil 1999;80:236-8.

8. Warden SJ, Burr DB, Brukner PD. Stress fractures: pathophysiology, epidemiology, and risk factors. Curr Osteoporos Rep 2006;4:103-9.

9. Umans $H$, Pavlov $H$. Stress fractures of the lower extremities. Semin Roentgenol 1994;29:176-93.

10. Conway SP, Morton AM, Oldroyd B, Truscott JG, White H, Smith $\mathrm{AH}$, et al. Osteoporosis and osteopenia in adults and adolescents with cystic fibrosis: prevalence and associated factors. Thorax 2000;55:798-804.

11. Bianchi ML, Romano G, Saraifoger S, Costantini D, Limonta C, Colombo C. BMD and body composition in children and young patients affected by cystic fibrosis. J Bone Miner Res 2006;21:388-96.

12. Sermet-Gaudelus I, Souberbielle JC, Ruiz JC, Vrielynck S, Heuillon B, Azhar I, et al. Low bone mineral density in young children with cystic fibrosis. Am J Respir Crit Care Med 2007;175:951-7.

13. Elkin SL, Vedi S, Bord S, Garrahan NJ, Hodson ME, Compston JE. Histomorphometric analysis of bone biopsies from the iliac crest of adults with cystic fibrosis. Am J Respir Crit Care Med 2002;166:1470-4.

14. King SJ, Topliss DJ, Kotsimbos T, Nyulasi IB, Bailey M, Ebeling PR, et al. Reduced bone density in cystic fibrosis: DeltaF508 mutation is an independent risk factor. Eur Respir J 2005;25:54-61.

15. Werntz JR, Lane JM. The biology of pathologic fracture repair. In: Lane JM, Healey JH, (editors). Diagnosis and management of pathologic fractures. New York: Raven; 1993; p. 1-11.

16. Pouilles JM, Bernard J, Tremollières F, Louvet JP, Ribot C. Femoral bone density in young male adults with stress fractures. Bone 1989;10:105-8. 
17. Consensus development conference: prophylaxis and treatment of osteoporosis. Am J Med 1991;90:107-10.

18. Fullerton LR Jr, Snowdy HA. Femoral neck stress fractures. Am J Sports Med 1988;16:365-77.

19. Robertson GA, Wood AM. Femoral Neck Stress Fractures in Sport: A Current Concepts Review. Sports Med Int Open 2017;1:E58-E68.

20. Biz C, Berizzi A, Crimì A, Marcato C, Trovarelli G, Ruggieri P. Management and treatment of femoral neck stress fractures in recreational runners: a report of four cases and review of the literature. Acta Biomed 2017;88:96-106.

21. Lim AY, Isopescu S, Thickett KM, Gumery LB, Darby AJ, Honeybourne $D$, et al. Bilateral fractured neck of the femur in an adult patient with cystic fibrosis. Eur J Intern Med 2003;14:196-8.

22. Haworth CS, Freemont AJ, Webb AK, Dodd ME, Selby PL, Mawer $E B$, et al. Hip fracture and bone histomorphometry in a young adult with cystic fibrosis. Eur Respir J 1999;14:478-9. 